\begin{tabular}{c} 
International Journal of Advanced Geosciences, 2(2)(2014) 133-139 \\
International Journal of Advanced Geosciences \\
Journal home page: $\begin{array}{c}\text { www.sciencepubco.com/index.php/IJAG } \\
\text { doi: } 10.14419 / \text { ijag.v2i2.3501 } \\
\text { Research Paper }\end{array}$ \\
\hline
\end{tabular}

\title{
Groundwater contamination due to salt-panning activity and seawater intrusion at Tuticorin coastal zone, southern Tamil Nadu, India
}

\author{
Singaraja $\mathrm{C}^{1 *}$, Chidambaram $\mathrm{S}^{2}$, Anandhan $\mathrm{P}^{2}$, Tariq Abdul Kareem $\mathrm{K}^{3}$ \\ ${ }^{1}$ Department of Geology, Presidency College, Chennai-60005, India \\ 2 Department of Earth Sciences, Annamalai University, Annamalai Nagar-608002, India \\ ${ }^{3}$ Department of Applied Geology, University of Madras, Chennai-5, India \\ *Corresponding authorE-mail: geolionking@gmail.com
}

\begin{abstract}
An attempt was made for the first time in the state of Tamil Nadu to assess the impact of saltpan and salt water intrusion effluent on available water sources existing in and around saltpans. A total of 48 water samples from different sampling sites were collected along coastal line and analyzed for physicochemical parameters such as $\mathrm{Na}^{+}, \mathrm{Ca}^{2+}, \mathrm{Mg}^{2+}, \mathrm{K}^{+}, \mathrm{Cl}^{-}, \mathrm{SO}^{2-}{ }_{4}$ and $\mathrm{HCO}_{3}^{-}$during Pre-monsoon. $\mathrm{Re}-$ sults indicate both higher $\mathrm{Cl}^{-}$and $\mathrm{SO}^{2-}{ }_{4}$ concentration in water samples from salt pans than in water samples from other sources. In addition to ratio of $\mathrm{Cl}^{-} / \mathrm{HCO}_{3}^{-}$and $\mathrm{Na}^{+} / \mathrm{Cl}^{-}$were clearly indicated that relationships of salt pan contamination and seawater intrusion. It is also clearly evident that moles ratio of $\mathrm{SO}^{2-}{ }_{4} / \mathrm{Cl}^{-}$vs $\mathrm{Cl}^{-}$and ternary plot differentiated the salt pan and seawater contaminated in the study area. The result obtained conclusively suggests the detrimental impact of saline effluent on water quality in Tuticorin coastal area, rendering it unsuitable for the propagation of life and unfit for agricultural purpose. And this indicates a worse condition of salt pan vicinities, as the ground water is only source of drinking water in those places.
\end{abstract}

Keywords: Saltpan; Seawater Intrusion; Physicochemical.

\section{Introduction}

Salinization of coastal fresh water aquifers by seawater intrusion, geomorphic changes, tidal waves, cyclonic storms and man-made hazards are major causes of the ground water pollution in the coastal areas of the Tamil Nadu, India. Studies of groundwater salinization by sea water intrusion in coastal areas in general, But Differentiating salt pan contaminated area from those of seawater incursion area is difficult. Very few literature are available for salt pan contaminated region such as Deuterium and oxygen-18 isotopes study on groundwater salinization of adjoining salt pans in Porbandar coast, Gujarat, India (Chandrasekharan et al. 1997), groundwater contamination due to salt pan along Mumbai coastal zone (Chandrasekharan et al. 2000). Singaraja et al. (2013b) preliminary find out the salt pan contaminate in Tuticorin coastal region. Many of the groundwater in the coastal aquifer is suffering from seawater intrusion by over-abstraction and water quality degradation due to urbanization and agricultural activities. Groundwater pollution has been reported in megacities, as well as in agricultural lands (Burt et al. 1993; Appelo and Postma, 2005; Singaraja et al. 2013a). Intrusion of saline waters in coastal regions occurs naturally, and can be exacerbated due to exploitation of coastal aquifers as water sources (Ozler, 2003; Prasanna et al. 2010; Thilagavathi et al. 2012).

In this scenario salinity problem in the coastal hard rock aquifers has gained its importance due to the lesser quantity of available fresh groundwater. This situation becomes more critical if the region has industrial estates, with urban cities, salt pans, and aquaculture ponds and with extensive agriculture activities. One such region is the area considered for study, Tuticorin falling on south eastern part of the India. Tuticorin coast attracts various wetland features like creek, coastal sand dune, and mangrove ecosystem. Extensive beach sand dunes enriched with deposits of black sand are seen (Chandrasekar et al. 2011). Industrial area has also been slowly increasing with a number of major and smallscale industries coming up in Tuticorin. The types of industries found here include petrochemicals, thermal power plant, Heavy Water Plant (HWP), chlor-alkali, $\mathrm{HCl}$, trichloro-ethylene, cotton and staple yarn, caustic soda, poly vinyl chlorine resin, fertilizers, soda-ash, and aromatics. Salt is produced on an extensive scale in Tuticorin as the district constitutes $70 \%$ of the total salt production of the state and meets almost $30 \%$ of the requirement of the country. Climate, soil and availability of brine make it conducive for salt production, and salt pans form the second largest land use class in this region. Within a span of twelve years, salt pan area has increased at the expense of agricultural land, coastal sand with/without vegetation, sand dunes, scrub and mud- flats (Gangai and Ramachandran, 2010). This trend is a cause of concern as these pans are fed by both bore wells and sea brine, and this has seriously affected the groundwater table. Further, once agricultural land has been converted into salt pans, the fertility of the soil is lost.

A holistic study to derive behavior of the groundwater chemistry and its differentiated to salt pan contamination and sea water intrusion of the study area has not been attempted. This study aims to determine the status of the salt pan contamination and sea water intrusion by using the major cations and anions and also to derive 
the other possible mechanism responsible for the groundwater chemistry of the region.

\section{Study area}

The present study area is, situated in the southeast coast of Tamil Nadu, India. It is located between $8^{\circ} 19^{\prime}$ to $9^{\circ} 10^{\prime} \mathrm{N}$ latitude and $77^{\circ} 04^{\prime}$ to $78^{\circ} 23^{\prime}$ E longitude (Fig.1) covering an area of about $1115 \mathrm{Km}^{2}$. The salt pans in the basin have been use for salt manufacture for the past 70 years. The area experiences a hot tropical climate. The average annual temperature from $23^{\circ} \mathrm{C}$ to $29^{\circ} \mathrm{C}$ and the annual rainfall is about $570 \mathrm{~mm}$ to $740 \mathrm{~mm}$.

\subsection{Geomorphology of the area}

The salt pans are located in the coastal depression of Tuticorin coastal region which extends from a nearby, many villages like Mullakkadu, Mudukkadu, Veppalodai, Toppasipatti, near
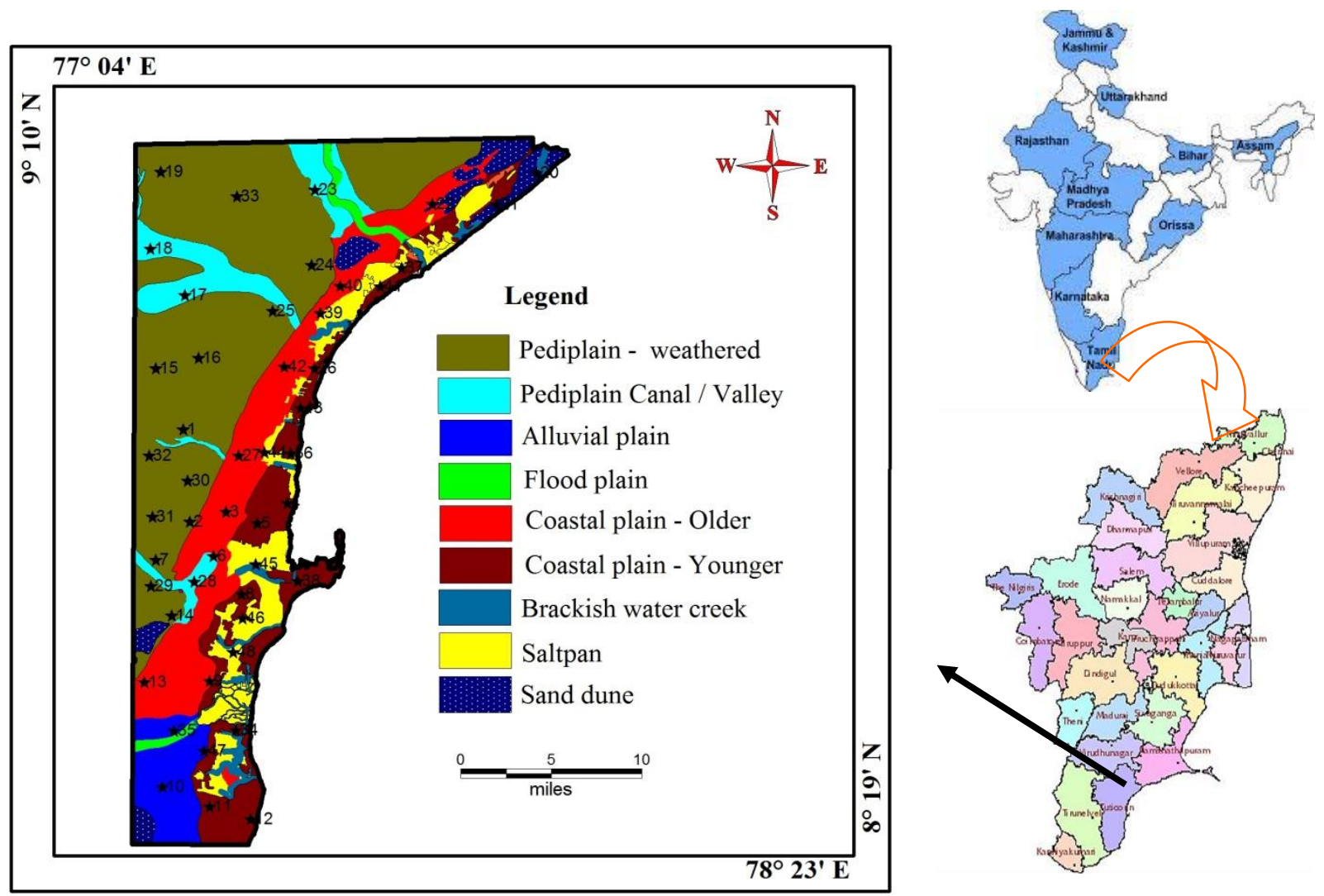

Fig. 1: Sample location and Geomorphology map of the study area

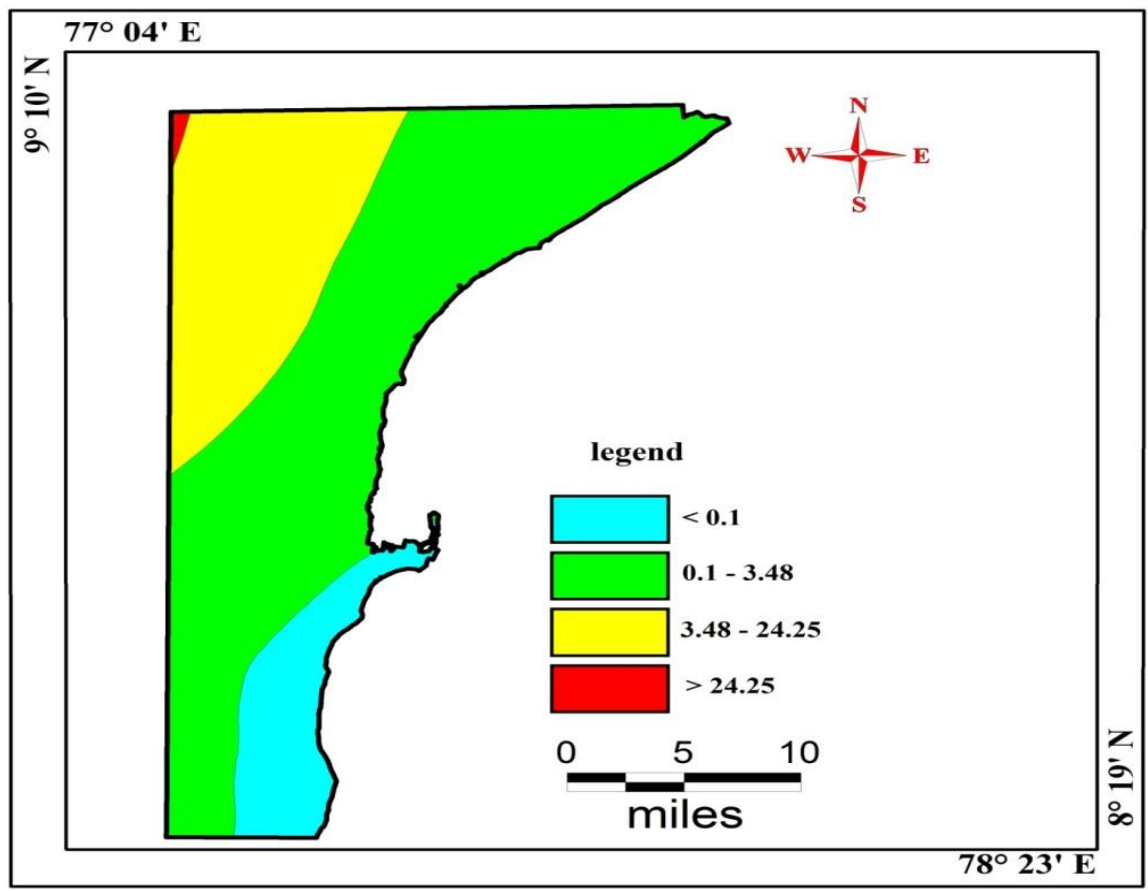

Fig. 2: Water level map of the study area during study period (All values in m AMSL) 
Taruvaikulam, Panaiyur and Kallurani. There are older, younger, alluvial plain deposits along the sea coast. Pediplain presented in northwestern part followed by few batches of sand dune coved in the study area (Fig. 1).

\subsection{Hydrological features}

The area adjacent to salt works is covered by a thin layer of soil along the coast line, groundwater conditions were determined by an inventory of 20 open wells. The depth to water level in the study area varied between -4.70 to $24.25 \mathrm{~m}$ AMSL. It is also noted that most of the wells range from -4.70 to $3.48 \mathrm{~m}$ AMSL along coastal region, except a few which have deeper water levels apart from coast (Fig. 2). Groundwater generally moves from land side towards salt pans and also from coastal side although there are local changes in the flow direction.

\section{Materials and methods}

A total of 48 groundwater samples (Fig.1) were collected in during PRM. The sample bottles were labeled, sealed, and transported to the laboratory under standard preservation methods. The major anionic and cationic concentrations were determined in the laboratory using the standard analytical procedures (Table 1).

\section{Results and discussions}

\subsection{Hydro geochemistry}

Groundwater from the study area is neutral to alkaline with $\mathrm{pH}$ ranging from 6.30 to 9.20 . Maximum value was noted that salt pan region eastern part of the study area, the similar trend was observed from darling pans (Smith et al. 2004). EC values ranges from $308 \mu \mathrm{s} / \mathrm{cm}$ to $37500 \mu \mathrm{s} / \mathrm{cm}$ and TDS ranges from $194 \mathrm{mgl}^{-1}$ and $23699 \mathrm{mgl}^{-1}$ respectively. Higher concentration was noted that study area indicating effective leaching of ions into the groundwater system during recharge and seawater intrusion, similar trend was also observed in Cuddalore coastal region (Singaraja et al. 2012a).

Among the cations, the concentrations of $\mathrm{Na}^{+}, \mathrm{Ca}^{2+}, \mathrm{Mg}^{2+}$ and $\mathrm{K}^{+}$ ions ranged from 22.70 to $6896.00,4.00$ to $680.00,4.80$ to 1248.00 and 0.50 to $255.00 \mathrm{mgl}^{-1}$, with an average of 1732.55 , $138.77,267.56$ and $73.48 \mathrm{mgl}^{-1}$, respectively. The order of abundance is $\mathrm{Na}^{+}>\mathrm{Mg}^{2+}>\mathrm{Ca}^{2+}>\mathrm{K}^{+}$. For the anions, the concentrations of $\mathrm{Cl}^{-}, \mathrm{HCO}_{3}^{-}$, and $\mathrm{SO}^{2-}$ falls between 53.18 to 12658.78 , 24.40 to 431.00 and 0.50 to $3096.00 \mathrm{mgl}^{-1}$ respectively, with an average of $1767.30,178.36$ and $766.70 \mathrm{mgl}^{-1}$. The order of their abundance is $\mathrm{Cl}^{-}>\mathrm{HCO}_{3}^{-}>\mathrm{SO}^{2-}$. The maximum, minimum, and average values of groundwater chemical constituents are given in Table 2 .

\subsection{Evident for salt pan contaminant and seawater in- trusion}

\subsection{1. $\mathrm{Cl}^{-} / \mathrm{HCO}_{3}^{-}$ratio}

The ratios of $\mathrm{Cl}^{-} / \mathrm{HCO}_{3}^{-}$ranged between 0.41 and 152.50 and had strong positive linear relation with $\mathrm{Cl}^{-}$concentrations with $\mathrm{R}^{2}$ value of 0.82 (Fig. 3). This linear relationship indicates simple mixing of fresh groundwater with salt pan and saline waters. It's also interesting to note that there is slight deviation in the linear relationship at the lower range of the mole ratios this is mainly due to the variation in the $\mathrm{HCO}_{3}^{-}$values. The decrease of this $\mathrm{HCO}_{3}^{-}$ion represents in the increase of the $\mathrm{Cl}^{-} / \mathrm{HCO}_{3}^{-}$ratio even at the lower values of the $\mathrm{Cl}^{-}$represented in the ' $\mathrm{X}$ ' axis. This decrease of $\mathrm{HCO}_{3}^{-}$value or increase of $\mathrm{Cl}^{-}$relatives to $\mathrm{HCO}_{3}^{-}$ions, ie mainly may be due to land use patter (percolation of salt pans) along the coast region of the study area.

Simpson classification includes five classes: $<0.5$ for good quality water, 0.5 to 1.3 for slightly contaminated water, 1.3 to 2.8 moderately for contaminated water, 2.8 to 6.6 injuriously contaminated and $>15.5$ for highly contaminated water. Considering the threshold value of $\mathrm{Cl}^{-}$concentration $(63 \mathrm{mg} / \mathrm{l})$ and the ratio of $\mathrm{Cl}^{-} / \mathrm{HCO}$ 3 , it was found that about $29 \%$ of the groundwater was strongly affected by the saline water, $15 \%$ were slightly, $54 \%$ moderately affected and $2 \%$ of samples were not affected by sea water. The most of the ground waters show the strong contamination with sea water. It is also interesting point note that lesser amount of $\mathrm{HCO}_{3}^{-}$ is also contributed to the groundwater through oxidation of organic matter as a byproduct of $\mathrm{SO}^{2-}{ }_{4}$ reduction (Lyons et al. 1984; Compton, 1988; Last, 1990). As chloride is the dominant ion found in salt pan and seawater while bicarbonate is present only in very small amounts (Singaraja et al. 2013b; Singaraja et al. 2014).

\subsection{2. $\mathrm{Na}^{+} / \mathrm{Cl}^{-}$moles ratio}

Moles ratios of $\mathrm{Na}^{+} / \mathrm{Cl}^{-}$versus $\mathrm{Cl}^{-}$concentrations indicate that ratio values of groundwater falling near the seawater ratio $(0.86)$ indicate that fresh groundwater were contaminated with the saline waters. The $\mathrm{Na}^{+} / \mathrm{Cl}^{-}$ratios ranged from 0.33 to 8.32 in the present study area. The ratio of $\mathrm{Cl}^{-}$to $\mathrm{Na}^{+}$and $\mathrm{Mg}^{2+}$ indicate a predominant seawater source for these ions. Water near to the coast often has a composition similar to seawater from wet and dry deposition of cyclic salts from the salt pan regions that originate as sea-spray or vapour, or from dissolution of salt formed by evaporation of a remnant of seawater (Herczeg and Lyons, 1991). The amount of $\mathrm{Na}+$ released into solution by feldspar weathering is relatively minor compared to the large contribution from coastal rainfall, but enrichment is observed in dilute ground waters with $\mathrm{Na}^{+} / \mathrm{Cl}^{-}>1$.

Table 1: Summary of the methods, instruments and make, critical reference materials along with their brands used for the analysis of ions in the given study

\begin{tabular}{|c|c|c|c|c|}
\hline $\begin{array}{l}\text { Chemical } \\
\text { Parameter }\end{array}$ & Units & $\begin{array}{l}\text { Methods and } \\
\text { Instrument (make) }\end{array}$ & Reagents (make) & $\begin{array}{l}\text { Methodology } \\
\text { References }\end{array}$ \\
\hline $\mathrm{pH}$ & & pH meter (SYSTRONICS) & pH 4.1, 7.0, and 10 (buffer solutions) THERMO ORION & APHA (1992) \\
\hline EC & $\mu \mathrm{S} / \mathrm{cm}$ & EC meter (SYSTRONICS) & $1413 \mathrm{~ms} / \mathrm{cm}$ Orion application solution, THERMO ORION & APHA (1992) \\
\hline TDS & $\mathrm{mgl}^{-1}$ & TDS meter (HANNA) & $692 \mathrm{ppm}$ Orion application solution, THERMO ORION & APHA (1992) \\
\hline $\mathrm{Ca}^{2+}$ & $\mathrm{mgl}^{-1}$ & Volumetric & EDTA, Sodium hydroxide and Murexide (MERCK) & APHA (1992) \\
\hline $\mathrm{Mg}^{2+}$ & $\mathrm{mgl}^{-1}$ & Volumetric & $\begin{array}{l}\text { EDTA, Sodium hydroxide, Ammonia buffer and } \\
\text { Erichrome black -T ( MERCK ) }\end{array}$ & APHA (1992) \\
\hline $\mathrm{Na}^{+}$ & $\mathrm{mgl}^{-1}$ & $\begin{array}{l}\text { Flame photometer } \\
\text { ( ELICO ) }\end{array}$ & $\begin{array}{l}\text { Sodium chloride }(\mathrm{NaCl}), \mathrm{KCl} \text { and } \\
\text { Calcium carbonate }\left(\mathrm{CaCO}_{3}\right)(\text { MERCK })\end{array}$ & APHA (1992) \\
\hline $\mathrm{K}^{+}$ & $\mathrm{mgl}^{-1}$ & Flame photometer (ELICO) & $\mathrm{NaCl}, \mathrm{KCl}$ and $\mathrm{CaCO}_{3}(\mathrm{MERCK})$ & APHA (1992) \\
\hline $\mathrm{HCO}_{3}^{-}$ & $\mathrm{mgl}^{-1}$ & Volumetric & $\begin{array}{l}\text { Hydrosulfuric acid }\left(\mathrm{H}_{2} \mathrm{SO}_{4}\right) \text {, Phenolphthalein and } \\
\text { Methyl orange ( MERCK ) }\end{array}$ & APHA (1992) \\
\hline $\mathrm{Cl}^{-}$ & $\mathrm{mgl}^{-1}$ & Volumetric & Silver nitrate, Potassium chromate ( MERCK ) & APHA (1992) \\
\hline $\mathrm{SO}_{4}^{2-}$ & $\mathrm{mgl}^{-1}$ & $\begin{array}{l}\text { UV-Vis Double Beam Spectrophotometer } \\
\text { (ELICO) }\end{array}$ & $\begin{array}{l}\text { Glycerol, } \mathrm{HCl} \text {, Ethyl alcohol, } \mathrm{NaCl} \text {, Barium chloride and Sodium sulphate ( } \\
\text { MERCK ) }\end{array}$ & $\begin{array}{l}\text { Eaton et al. } \\
(1995)\end{array}$ \\
\hline
\end{tabular}




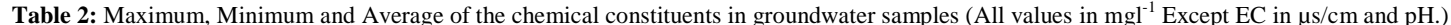

\begin{tabular}{|c|c|c|c|c|c|c|c|c|c|c|}
\hline & $\mathrm{pH}$ & $\mathrm{EC}$ & TDS & $\mathrm{Ca}^{2+}$ & $\mathrm{Mg}^{2+}$ & $\mathrm{Na}^{+}$ & $\mathrm{K}^{+}$ & $\mathrm{Cl}^{-}$ & $\mathrm{SO}_{4}^{2-}$ & $\mathrm{HCO}_{3}^{-}$ \\
\hline Max & 9.20 & 37500 & 23699 & 680.00 & 1248.00 & 6896.00 & 255.00 & 12658.75 & 3096.00 & 431.00 \\
\hline Min & 6.30 & 308 & 194 & 4.00 & 4.80 & 22.70 & 0.50 & 53.18 & 0.50 & 24.40 \\
\hline Avg & 7.05 & 6523 & 3855 & 138.77 & 267.56 & 1732.55 & 73.48 & 1767.30 & 766.70 & 178.36 \\
\hline
\end{tabular}

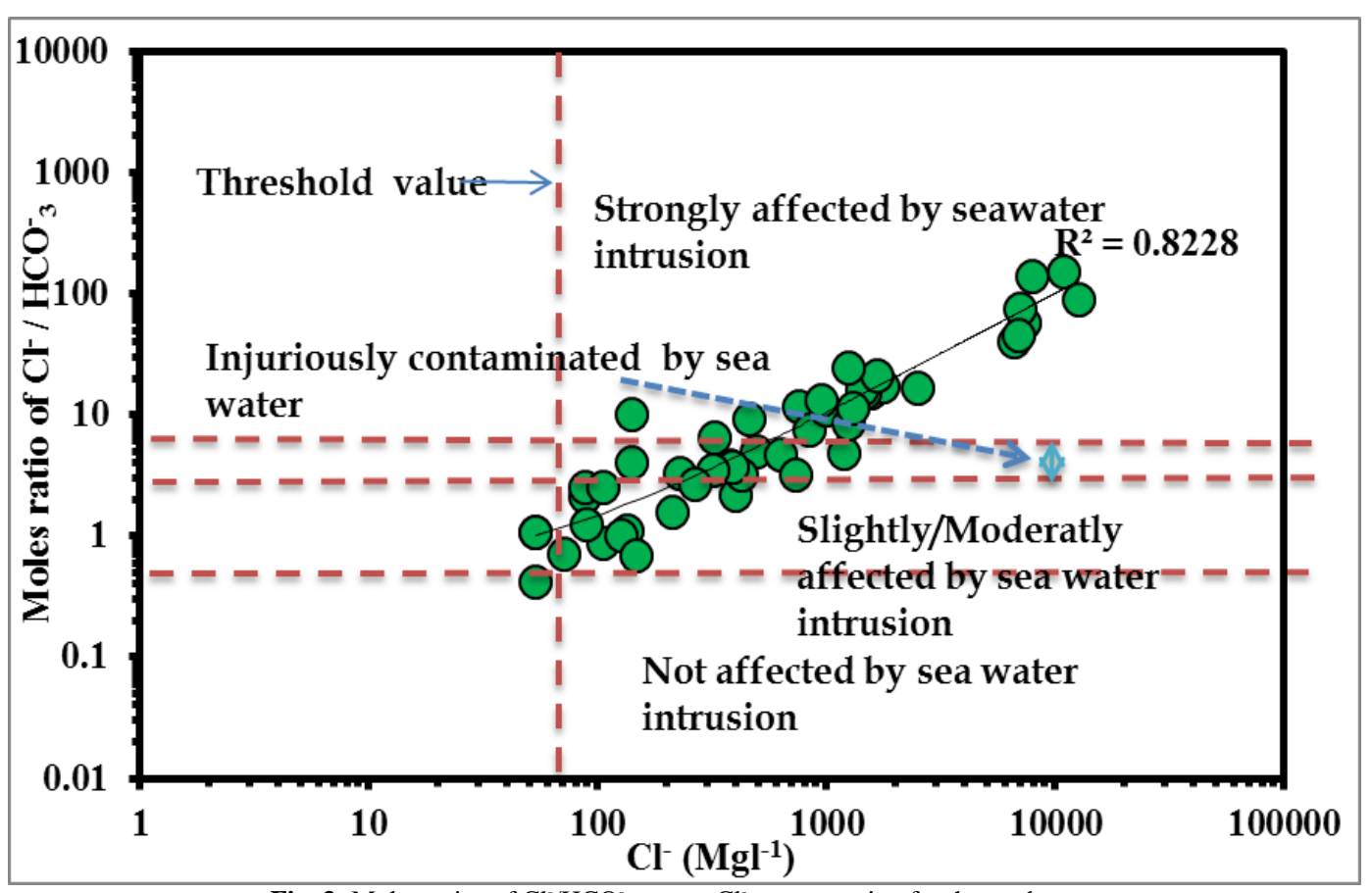

Fig. 3: Molar ratios of $\mathrm{Cl}^{-} / \mathrm{HCO}_{3}^{-}$versus $\mathrm{Cl}^{-}$concentration for the study area

The $\mathrm{Na}^{+} / \mathrm{Cl}^{-}$ratio show that $56 \%$ of the samples (Fig. 4) were above the seawater ratio, indicating a large proportion of groundwater was affected by seawater intrusion to certain degrees. It is also evident that very high $\mathrm{Na}^{+} / \mathrm{Cl}^{-}$ratios may be indicative of anthropogenic contamination, like salt pans (Jones et al.1999). It is also interesting to note that good correlation exists between $\mathrm{SO}^{2-}$ and $\mathrm{Cl}^{-}$and in certain locations they fall above and below the equiline. But samples are also fall above the equiline (Fig. 5), which may also be due to the influence of the salt pans activity in these regions (Smith et al. 2004) such as Mullakkadu, Mudukkadu, Veppalodai, Toppasipatti, near Taruvaikulam, Panaiyur and Kallurani. This process may be enhanced in the study area mainly due to the leaching of the salts after the monsoon from the dried salt pans. The samples falling below the equiline of $\mathrm{SO}^{2-}{ }_{4}$ and $\mathrm{Cl}^{-}$indicate sea water intrusion (Singaraja et al. 2013b) like Diraspurm, harbor beach, Sippikulam and Sakkamalpurm. It also evident that negative water level $(-4.70 \mathrm{~m}$ AMSL) observed along the coastal region may be due to saltwater intrusion (Fig. 2).

Seawater has distinct ionic ratios such as $\mathrm{Na}^{+} / \mathrm{Cl}^{-}=0.86, \mathrm{SO}^{2-}{ }_{4} / \mathrm{Cl}^{-}$ $=0.05 ; \mathrm{Ca}^{2+} /\left(\mathrm{HCO}_{3}^{-}+\mathrm{SO}^{2-}\right)$ and $\mathrm{Mg}^{2+} / \mathrm{Ca}^{2+}=5.2$ (Vengosh et al. 2002; Vengosh and Rosenthal 1994). The minimum and maximum values of these ratios in the samples of the study area are given in (Table 3). The $\mathrm{Na}^{+} / \mathrm{Cl}^{-}$ratio is greater than unity in about $67 \%$ of the samples of the study area. The $\mathrm{Na}^{+} / \mathrm{Cl}^{-}$molar ratio could reach unity due to the mixing of seawater and freshwater (Vengosh and Rosenthal 1994). Relative to seawater, the groundwater has relatively low $\mathrm{Na}^{+} / \mathrm{Cl}^{-}$ratios in many samples $(0.20$ 3.73), high $\mathrm{Mg}^{2+} / \mathrm{Ca}^{2+}$ ratios and high $\mathrm{Ca}^{2+} /\left(\mathrm{HCO}_{3}^{-}+\mathrm{SO}_{4}^{2-}\right)$ ratios (greater than unity) (Vengosh et al. 2002, Mondal et al. 2010).The $\mathrm{Mg}^{2+} / \mathrm{Ca}^{2+}$ ionic ratio greater than 5 is a direct indicator of seawater contamination as noted in few samples of the study area.

High $\mathrm{SO}^{2-}{ }_{4} / \mathrm{Cl}^{-}$ratio is attributed to the application of gypsum fertilizers (Vengosh et al. 2002). Higher $\mathrm{SO}^{2-}{ }_{4}$ values comparative to the $\mathrm{Cl}^{-}$values may also due to the influence of the salt pans in the region (smith et al. 2004). It is also clearly find that ternary plot (Fig. 6) distributed the salt pan contaminated region and saltwater intrusion region in the study area. Lesser values of $\mathrm{K}^{+} / \mathrm{Cl}^{-}$ and $\mathrm{SO}^{2-}{ }_{4} / \mathrm{Cl}^{-}$indicate aquifers with relatively lesser anthropogenic impact. $\mathrm{K}^{+}$seems to be also contributed from anthropogenic sources, this finding get strengthen by the comparison of $\mathrm{K}^{+} / \mathrm{Cl}^{-}$ ratio that found quite higher and equivalent to waste water infiltration. $\mathrm{Ca}^{2+} /\left(\mathrm{HCO}_{3}^{-}+\mathrm{SO}_{4}^{2-}\right)$ ratio depicts Sea water intrusion process in most of the samples and but still the ratios may also result from several complex reactions in the aquifer (Kumar et al. 2006). When an aquifer has an underlying layer of saline water and is pumped by a well penetrating only the upper freshwater portion of the aquifer, a local rise of the interface below the well occurs. This phenomenon is known as upcoming (Singaraja 2011). The interface is near horizontal at the start of pumping. With continued pumping, the interface rises to progressively higher levels until eventually it reaches the well. This generally necessitates the well to be shut down because of the degrading influence of the saline water. When pumping is stopped, the denser saline water tends to settle downward and to return to its former position. Observations of all these ratios (Table 3) indicate that there is also a possibility of saline upcoming conditions in the study area. 


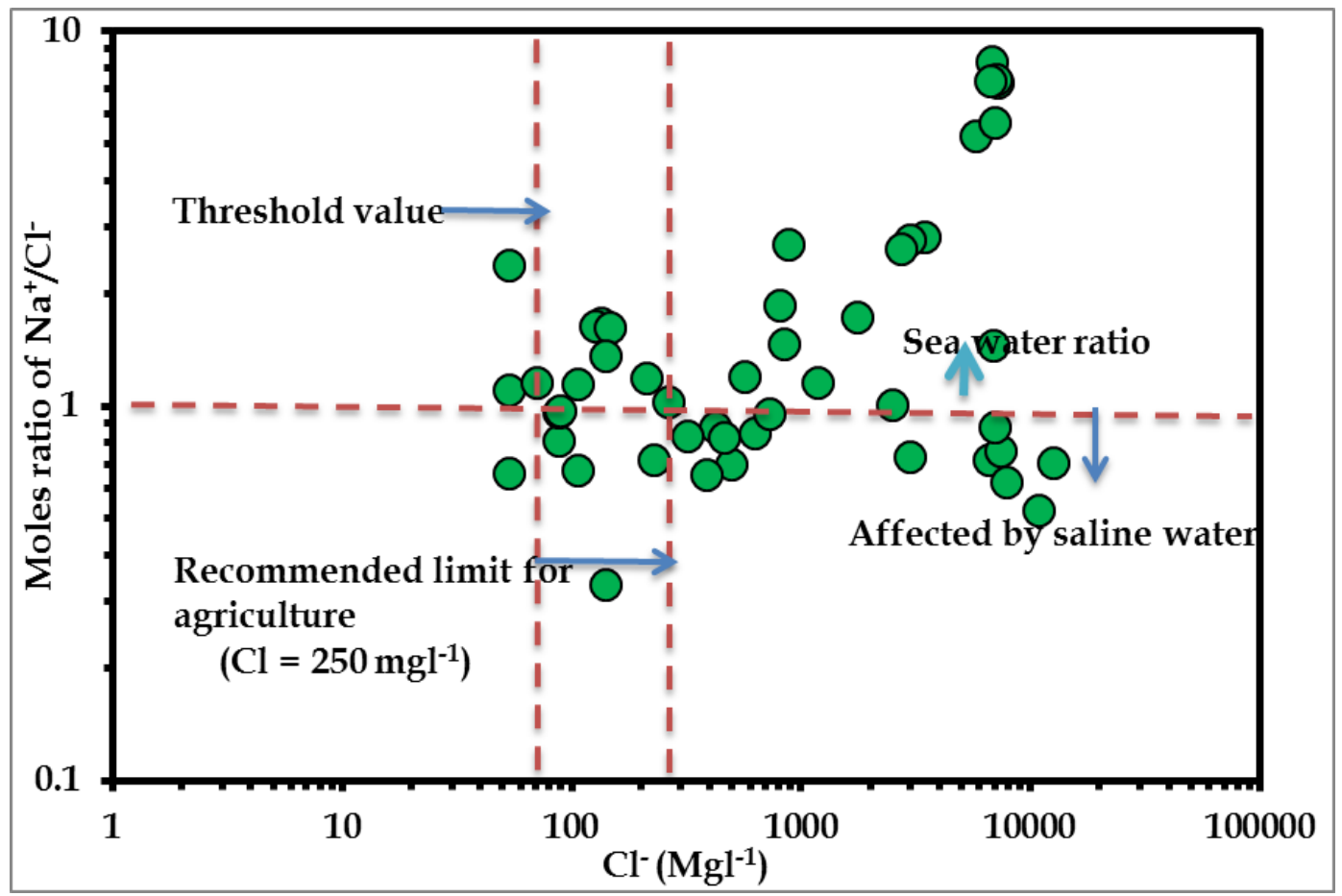

Fig. 4: Molar ratios of $\mathrm{Na}^{+} / \mathrm{Cl}^{-}$versus $\mathrm{Cl}^{-}$concentration

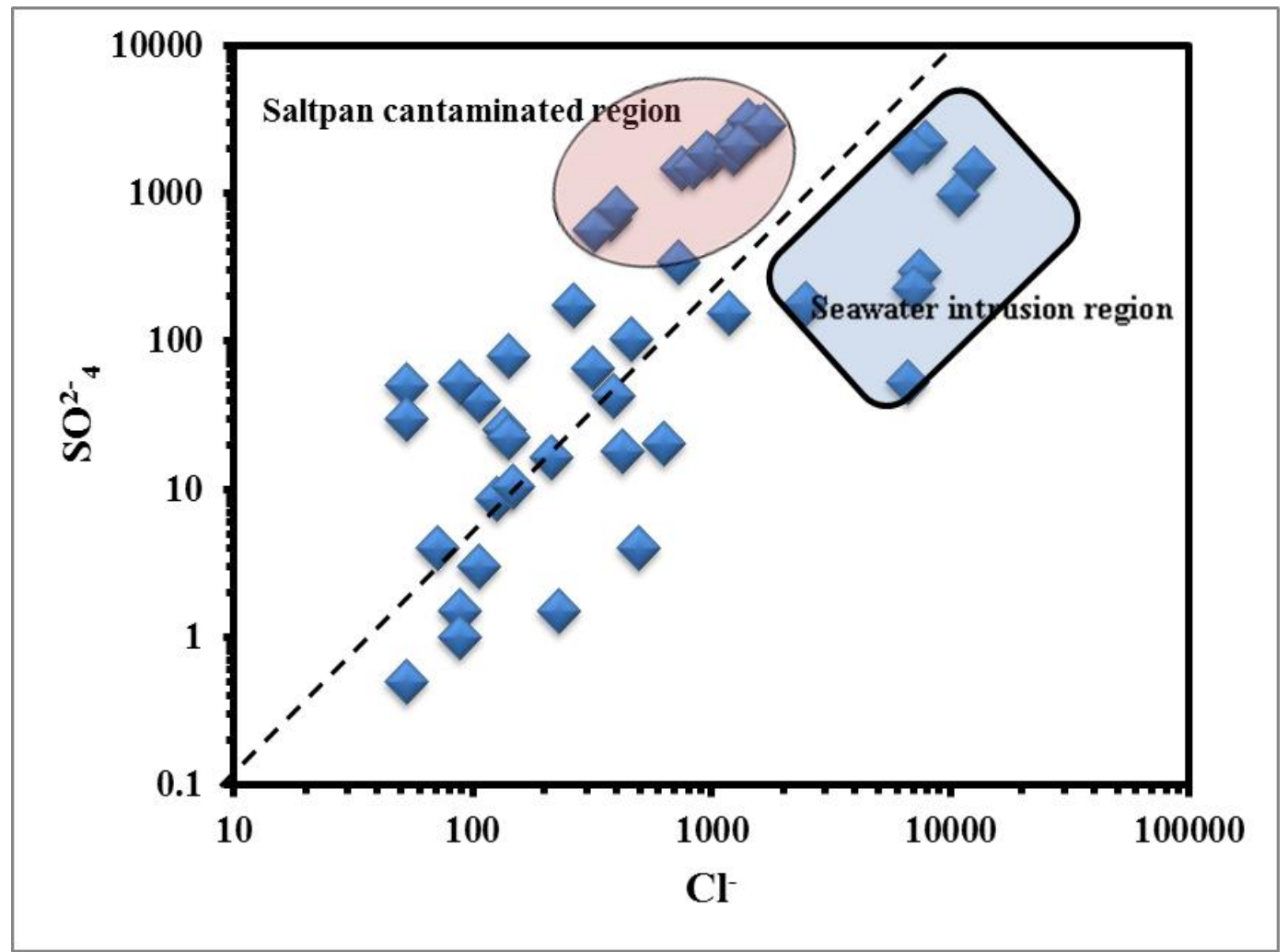

Fig. 5: Relationship between $\mathrm{Cl}^{-}$and $\mathrm{SO}^{2-}{ }_{4}$

Table 3: The comparative ionic ratio of potential salinization sources and study area groundwater parameter for seawater intrusion

\begin{tabular}{lllll}
\hline Parameter & $\begin{array}{l}\text { Seawater } \\
\text { intrusion }\end{array}$ & $\begin{array}{l}\text { Deep saline } \\
\text { up coning }\end{array}$ & $\begin{array}{l}\text { Agriculture } \\
\text { return flows }\end{array}$ & $\begin{array}{l}\text { Wastewater } \\
\text { infiltration }\end{array}$ \\
\hline $\mathrm{Na}^{+} / \mathrm{Cl}^{-}$ & $0.86-1^{\mathrm{a}}$ & $<0.8^{\mathrm{b}}$ & - & $1.1^{\mathrm{c}}$ \\
$\mathrm{SO}_{4}^{2-} / \mathrm{Cl}^{-}$ & $0.05^{\mathrm{a}, \mathrm{c}}$ & $* 0.05^{\mathrm{c}, \mathrm{d}}$ & $>>0.05^{\mathrm{e}}$ & $0.33-8.32$ \\
$\mathrm{~K}^{+} / \mathrm{Cl}^{-}$ & 0.019 & $<0.019$ & - & $-09^{\mathrm{d}}$ \\
$\mathrm{Mg}^{2+} / \mathrm{Ca}^{2+}$ & $>5^{\mathrm{b}}$ & $>1^{\mathrm{a}}$ & - & 0.02 \\
$\mathrm{Ca}^{2+} /\left(\mathrm{HCO}_{3}^{-}+\mathrm{SO}_{4}^{2-}\right)$ & $0.35-<1$ & $<1^{\mathrm{a}}$ & - & $0.0-0.273$ \\
\hline
\end{tabular}

a) Vengosh and Rosenthal (1994), b) Vengosh and Ben-Zvi (1994), c) Vengosh et al.(1994), d) Mercado (1985) and e) Vengosh et al. (2002) 


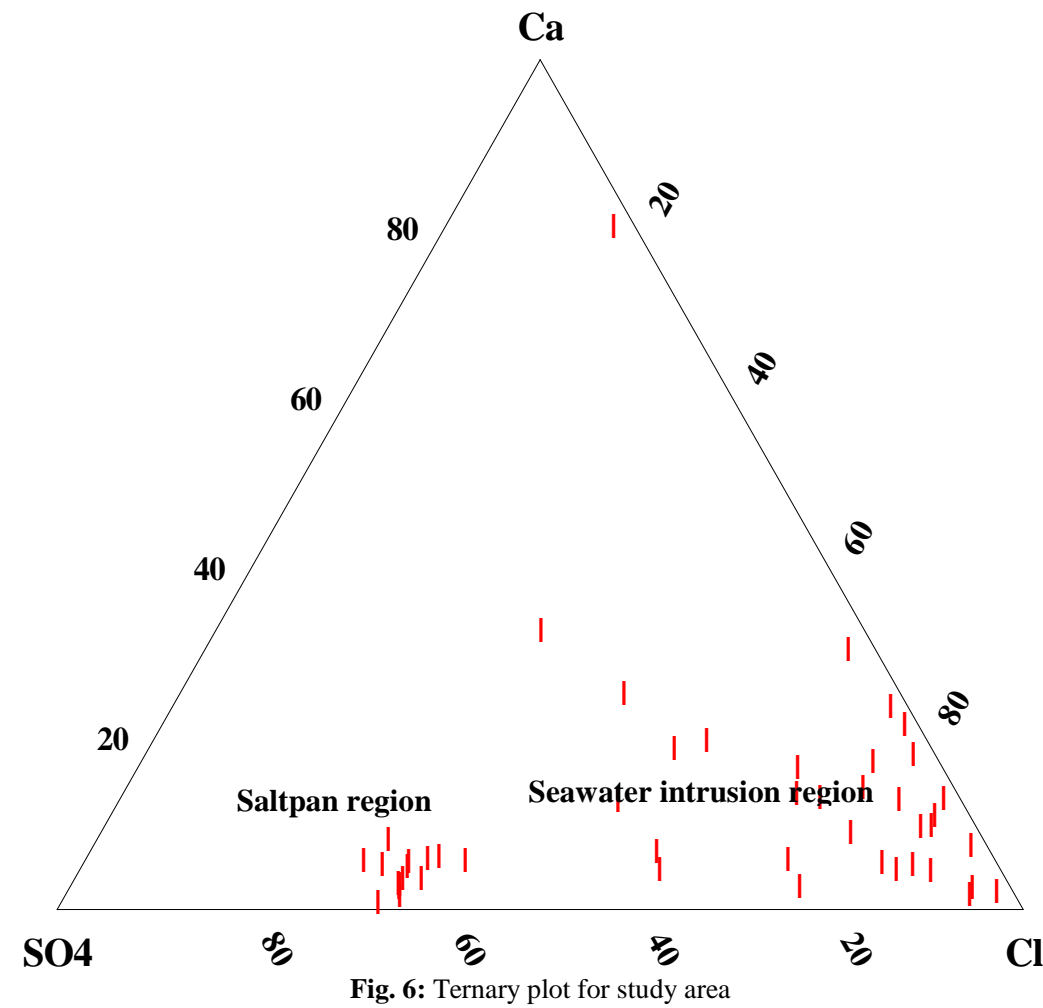

\section{Conclusion}

The above study indicates the ratio of $\mathrm{Cl}^{-} / \mathrm{HCO}_{3}^{-}$show that about $29 \%$ of the groundwater was strongly affected by the saline water. It is also noted that lesser amount of $\mathrm{HCO}_{3}^{-}$is also contributed to the groundwater through oxidation of organic matter by product of $\mathrm{SO}^{2-}{ }_{4}$ reduction may be due to salt pan contaminated in the study area. $\mathrm{Na}^{+} / \mathrm{Cl}^{-}$ratios may be indicative of anthropogenic contamination, like salt pans. Good correlation between $\mathrm{SO}^{2-}{ }_{4}$ and $\mathrm{Cl}^{-}$and in few locations they fall above the equiline which may be due to the influence of the salt pans activity in these regions. The samples falling below the equiline of $\mathrm{SO}_{4}^{2-}$ and $\mathrm{Cl}^{-}$indicate sea water intrusion.

\section{Acknowledgment}

We are thankful to Department of Earth Sciences, Annamalai University providing facilities and the authorities of various Salt Manufacturing Company, Tuticorin for help in conducting the investigations.

\section{References}

[1] APHA (1992) Standard methods for the examination of water and wastewater. Washington, DC: American Public Health Association, $326 \mathrm{p}$.

[2] Appelo CAJ, Postma D (2005) Geochemistry, Groundwater and Pollution, second ed. Balkema, Amsterdam. 649p http://dx.doi.org/10.1201/9781439833544.

[3] Burt TP, Haycock NE (1993) Controlling Losses of Nitrate by Changing Land Use. In: Nitrate: Processes, Patterns and Management. Edited by Burt TP, Heathwaite AL, Trudgill ST, John Wiley \& Sons, Chichester, $342-367$

[4] Chandrasekar N, Joevivek V, John Prince Soundaranayagam, Divya C (2011) Geospatial Analysis of Coastal Geomorphological Vulnerability along Southern Tamilnadu Coast, geospatial world forum.

[5] Chandrasekharan H, Gupta N, Navada SV (1997) Deuterium and oxygen-18 isotopes on groundwater salinization of adjoining salt pans in Porbandar coast, Gujarat, India, Hydrochemistry (Proceedings of the Rabat Symposium) IAHS Publ. no. 244.

[6] Compton JS (1988) Degree of supersaturation and precipitation of organogenic dolomite. Geol., 16, 318-321.
[7] Eaton AD, Clesceri L, Greenberg AE (1995) Standard Methods for the Examination of Water and Wastewater. 19th. American Public Health Association, Washington DC.

[8] Gangai IPD and Ramachandran S (2010) the role of spatial planning in coastal management: a case study of Tuticorin coast (India). Land Use Policy 27, pp.518- 534.

[9] Jeen SK, Kim JM, Ko KS, Yum B, Chang HW (2001) Hydrogeochemical characteristics of groundwater in a mid-western coastal aquifer system, Korea. Geosci J 5:339-348 .

[10]Joshi B S (1970). Studies on soils related to interaction between soils and salt solutions; soils and stabilizing agents and their application in salt manufacture, Ph.D. Thesis, Gujarat University.

[11]Kumar M, Ramanathan AL, Rao MS, Kumar B (2006) Identification and evaluation of hydrogeochemical processes in the groundwater environment of Delhi. India Environ geology 50:1025-1039.

[12]Last WM (1990) lacustrine dolomite-an overview of modern, Holocene, and Pleistocene occurrences. Earth Sci. Rev 27:221-263.

[13]Lyons WB, Long DT, Hines ME, Gaudette HE, Armstrong PB (1984) Calcification of cyanobacterial mats in Solar Lake, Sinai. Geol 12:623-626 http://dx.doi.org/10.1130/0091-7613.

[14]Mondal NC, Singh VP, Singh VS, Saxena VK (2010) Determining the interaction between groundwater and saline water through groundwater major ions chemistry. Journal of Hydrology 388:100 - 111

[15]Ozler MH (2003) Hydrochemistry and salt-water intrusion in the Van aquifer, east Turkey. Environ Geol 43:759 - 775.

[16]Prasanna MV, Chidambaram S, ShahulHameed A, Srinivasamoorthy K (2010) Study of evaluation of groundwater in Gadilam basin using hydrogeochemical and isotope data. Environ Monit Assess 168,63- 90

[17] Singaraja C (2011) Impact of tidal variation in shallow coastal groundwater of cuddalore district, unpublished M.Phil, thesis, 1-147. Department of Earth Sciences, Annamalai University

[18] Singaraja C, Chidambaram S, Prasanna MV, Thivya C, Thilagavathi R (2013b) Statistical analysis of the hydrogeochemical evolution of groundwater in hard rock coastal aquifers of Thoothukudi district in Tamil Nadu, India. Environ Earth Sci DOI 10.1007/s12665-013-24535 http://dx.doi.org/10.1007/s12665-013-2453-5.

[19] Singaraja C, Chidambaram S, Anandhan P, Prasanna MV, Thivya C, Thilagavathi R, Sarathidasan J (2013a) Hydrochemistry of groundwater in a coastal region and its repercussion on quality, a case studyThoothukudi district, tamilnadu, India. Arab J Geosci DOI 10.1007/s12517-012-0794-0.

[20]Singaraja C, Chidambaram S, Anandhan P, Prasanna MV, Thivya C, Thilagavathi R (2014) A study on the status of saltwater intrusion in the coastal hard rock aquifer of South India. Environ Dev Sustain DOI 10.1007/s10668-014-9554-5.

[21]Smith SJ, Andres R, Conception E, Lurz J (2004) Sulfur Dioxide Emissions: 1850-2000 (JGCRI Report. PNNL-14537). 
[22] Srinivasamoorthy K, Vasanthavigar M, Chidambaram S, Anandhan P, Manivannan R, Rajivgandhi R (2012) Hydrochemistry of groundwater from Sarabanga Minor Basin, Tamilnadu, India, Proceedings of the International Academy of Ecology and Environmental Sciences 2(3):193-203

[23] Srinivasamoorthy K, Vasanthavigar V, Chidambaram S, Anandhan P, Sarma VS (2011) Characterisation ofGroundwater Chemistry in an Eastern Coastal Area of Cuddalore District, Tamil Nadu. Journal Geological Society of India Vol.78: pp. 549-558.

[24]Thilagavathi R, Chidambaram S, Prasanna MV, Thivya C, Singaraja C, Jainab I (2012) A study on groundwater geochemistry and water quality in layered aquifers system of Pondicherry region, southeast In dia. Appl Water Sci 2:253-269. Doi: 10.1007/s13201-012-0045-2.

[25]Vengosh A, Rosenthal E (1994) Saline groundwater in Israel: It's bearing on the water crisis in the country. Journal of Hydrology 156:389-430.

[26]Vengosh A, Gill J, Davisson ML, Hudson GB (2002) A multiisotope $(\mathrm{B}, \mathrm{Sr}, \mathrm{O}, \mathrm{H}$, and $\mathrm{C}$ ) and age dating study of groundwater from Salinas Valley, California: hydrochemistry, dynamics, and contamination process. Water Resources Research 38 (1):1-17.

[27]Vengosh A, Heumann KG, Juraski S, Kasher R (1994) Boron isotope application for tracing sources of contamination in groundwater. Environmental Science Technology 28 (11):1968-1974. 